\title{
Some Psychosocial Determinants of Cyber-Intimate Image Diffusion: A Cross-Sectional Study among In-School Deaf Adolescents
}

\author{
Olufemi Timothy Adigun
}

Department of Educational Psychology and Special Education, University of Zululand, KwaDlangezwa 3886, KwaZulu Natal, South Africa

\begin{abstract}
This study determined some psychosocial variables on cyber-intimate image diffusion among in-school deaf adolescents from two states in North-Central Nigeria. A descriptive research design and a multistage sampling procedure were employed in identifying 186 deaf adolescents who participated in the study. Two hypotheses were formulated for the study. The theory of planned behaviour was adopted as a framework for the study. Data generated through the questionnaire were analysed using descriptive statistics of frequency count and simple percentage as well as inferential statistics of bivariate correlation and $t$-test at .05 level of significance. Sixty-five percent of the respondents were aged 16-19. All respondents used WhatsApp and 78\% had a Facebook profile. Findings revealed a positive significant relationship between emotional intelligence $(\mathrm{r}=.489 ; \mathrm{p}<0.05)$,

ARTICLE INFO

Article history:

Received: 6 March 2020

Accepted: 1 August 2020

Published: 25 December 2020

DOI: https://doi.org/10.47836/pjssh.28.4.07

E-mail address:

AdigunO@unizulu.ac.za

ISSN: 0128-7702

e-ISSN: 2231-8534

self-esteem $(r=.530 ; \mathrm{p}<0.05)$ and cyberintimate image diffusion. Also, significant differences were found between Christian and Muslim respondents $(\mathrm{t}=11.250 ; \mathrm{p}<$ $0.05)$; low and high emotional intelligence $(\mathrm{t}=-2.412 ; \mathrm{p}<0.05)$; low and high selfesteem $(\mathrm{t}=-11.958 ; \mathrm{p}<0.05)$ with regard to cyber-intimate intimate image diffusion. The study concludes that emotional intelligence and self-esteem are determinants of
\end{abstract}


cyber-intimate image diffusion among deaf adolescents. This study, therefore, recommends a synergy between parents of the deaf and professionals working with deaf adolescents to develop modalities that enhance psychological wellbeing and reduce cyber-intimate image diffusion among deaf adolescents.

Keywords: Cyber-intimate image diffusion, deaf adolescents, emotional intelligence, religion, selfesteem, spirituality

\section{INTRODUCTION}

The advent of computers, smartphones, and particularly the internet has significantly transformed communication models, especially among adolescents. Globally, adolescents form a larger percentage of internet users (Rai, 2017) through email usage, instant messaging and chat, blogging, web surfing, and social networking. Interestingly, previous studies have revealed the benefits associated with the use of the internet for education, psychosocial wellbeing as well as sexual and reproductive health. Also, studies have recently associated the use of cyber platforms and digital communication with social interaction and sexual expressions among adolescents (Oluwole, 2009; Scholes-Balog et al., 2016). Currently, cyberspace has been used as a means of sexting. Sexting has been described as the process whereby sexually explicit or intimate images and messages are shared through electronic gadgets, and particularly, through social networks
(Scholes-Balog et al., 2016). Sexting is regarded as risky sexual behaviour that has spread through all strata of society with a greater prevalence among adolescents (Marume et al., 2018). While previous studies (Englander \& McCoy, 2018; Klettke et al., 2014; Madigan et al., 2018) have used the term 'sexting', the term 'intimate image diffusion' (Penado et al., 2019) as a phenomenon associated with the exchange of sexually explicit or intimate images via social networking sites has been adopted for the purpose of this study.

As noted by Adigun (2020) and Penado et al. (2019), through the social networks (e.g. Facebook, WhatsApp, Instagram, and other social platforms) via mobile devices (smartphones or computer gadgets), adolescents have largely engaged in sending, receiving, broadcasting, and re-broadcasting of sexual or erotic contents and images. Since the 2008 published results of the National Campaign among adolescents in the United States, studies have shown that sexting and diffusion of sexual contents and images among adolescents is a common phenomenon. Depending on demographic characteristics, the prevalence of sending and receiving sexual images via social networks ranges from ten to forty percent especially among adolescents in primary and secondary schools (Penado et al., 2019). However, while the prevalence of diffusion of sexual/provocative contents and images is on the increase, Madigan et al. (2018), as well as Morelli et al. (2016) stated that a higher percentage of adolescents received images of sexual contents than 
sent them. In their studies, Harrison and Gilmore (2012), as well as Lindsay and Krysik (2012), established that females had higher tendencies to disclose personal and intimate images of themselves to their boyfriends or someone they were in a romantic relationship with or someone they intended to have a romantic relationship with. In fact, Kaur (2014) and Lawrence and Tokede (2017) avered that women often engaged in sending nude images of themselves to their romantic partner than they received.

There has been serious and unending debate among the scientific community about the implication of sexting and/or diffusion of sexual/intimate images among adolescents, especially about the associated negative effect on their mental, social, psychological, and sexual health. Temple and $\mathrm{Lu}$ (2018) indicated that diffusion of intimate sexual images, often resulting from (cyber) bullying, harassment, and humiliation was a negative and risky sexual behaviour capable of detrimental effects on mental health. Kopecký (2012) in a study among 9,353 adolescents from the Czech Republic found that the respondents engaged in sexual image sharing as a result of social pressure, boredom, self-representation and to make intimate contact. Furthermore, Lippman and Campbell (2014) stated that for adolescents, sharing of intimate messages and images could serve as a form of expression of sexuality and sexual interest as religion might have prevented them from premarital sexual exploration and contacts. Unfortunately, while a large number of studies on adolescents have explored various forms and implications of sexting and sharing of sexual/provocative images, the influence of psychosocial determinate of cyber-intimate diffusion among adolescents especially deaf adolescents is yet unknown. Hence, this study aimed to unravel the influence of psychosocial factors (age, gender, religion, spirituality, self-esteem, and emotional intelligence) on cyberintimate image diffusion among in-school deaf adolescents.

Deafness is a condition that results in a loss of sense of hearing. In other words, individuals who are deaf lack the required potential to respond to auditoryverbal stimuli. The condition of loss of hearing sensitivity may arise at any time in an individual's life (Adigun, 2020). Irrespective of the onset of deafness, about $90 \%$ of deaf children are raised by parents who are not deaf (Moroe \& De Andrade, 2018) resulting in heightened tension, grief, and anxiety within the family. Within the family and social context, the deaf experience communication difficulties especially when verbal communication forms the basis of social interactions. Although deaf people have and are expected to communicate via sign languages when assistive listening devices are unavailable, some studies have noted that sign language use has limitations particularly when the illumination is bad, or when considerable distance and obstruction are involved (Adigun, 2018; Bontempo, 2015; Napier \& Barker, 2004). Thus, many deaf have leveraged the advantages presented by 
social networking sites for communication and social interaction (Barak \& Sadovsky, 2008). According to Lenhart et al. (2010) as well as Anderson and Jiang (2018), the number of adolescent users of social networking sites has drastically increased to about $95 \%$ in 2018 from about $62 \%$ in 2009. However, Adigun (2020) stated that research finding was yet to determine the percentage of deaf adolescent users of the various social networking sites and the percentage of those who engaged in sexting and intimate image diffusion. In other words, there is a dearth of literature on sexting and intimate image diffusion among the deaf; but it is expected that deaf adolescents especially in Nigeria may not have been spared from the web of sexting and indiscriminate intimate image diffusion over cyberspace. This assumption is based on the fact that even when digital media is not involved, deaf adolescents actively engage in risky sexual behaviours (Adigun, 2020; Sangowawa et al., 2009). Therefore, with deaf adolescents' active engagement on social networking sites, this study hypothesized that the frequency of sexting and intimate image diffusion via social networking sites among deaf adolescents is significantly high.

The literature on sexting or intimate image diffusion among deaf adolescents is sparse but other extant literature among adolescents generally revealed variation in sexting or intimate image diffusion among adolescents in developed countries. Hence, this study employed literature from the nondeaf adolescents' population as a basis for comparison for the actual study participants.
For instance, Livingstone and Görzig's (2014) reported among Europeans aged 11-16 showed that about $15 \%$ of the study population had received sext and sexual/ intimate images online in the previous years. In another study, Willard (2010) noted that $20 \%$ of early adolescents in America had either sent or received sexual and provocative intimate images, while about $33 \%$ of late adolescents had posted online or electronically sent or received a sexually suggestive image via the social networks. According to Willard (2010), diffusion of an intimate image is not gender-specific as both male and female adolescents engage in the behaviour. In his study, Willard reported that about $18 \%$ and $12 \%$ of early adolescents engaged in sexting while among late adolescents, $36 \%$ of males and $31 \%$ of females reportedly sext. A study among Australian adolescents by Scholes-Balog et al. (2016), was consistent with earlier studies of Willard (2010) and Klettke et al. (2014) who stated that adolescents had a greater tendency to engage in sexting and diffuse sexual and intimate images via social networking sites (SNSs) such as WhatsApp, Facebook, and Instagram. Unfortunately, until now, the implication of age and gender of deaf adolescents on sexting and intimate image diffusion remains unexplored in previous studies but Scholes-Balog et al. (2016) noted that irrespective of gender, adolescents tended to be more comfortable with exploration and exchange of sexually explicit messages or images with romantic partners. 
Globally, the influence of religion and spirituality on sexuality among adolescents especially with the role played by digital media is still contentious in research (Apostolides, 2017; Quinn \& Lewin, 2019). According to Apostolides (2017), religion and spirituality are two different phenomena; spirituality is developed from religious practices and experiences. Rostosky et al. (2004) avered that religion played a vital role during adolescence especially with regard to sexual exploration and identification but that religious participation tended to decrease with age. Findings of De Visser et al. (2007) among other studies on the influence of religious affiliation and participation on adolescents' sexual behaviour have yielded mixed results. Another study attests that adolescents' regular participation in affiliated religious activities is associated with higher tendencies for abstinence, less potential for premarital sex, sexting, and other risky sexual behaviours as well as delayed in first sexual initiation and experience (De Visser et al., 2017).

Irrespective of religious affiliation and participation, Bankole and Malarcher (2010) stated that the level of spirituality among religious event attendees was different. In addition, Apostolides (2017) noted that spirituality and identity formation were complex layers that shape experience and social interaction even in cyberspace. In other words, the implication of spirituality on adolescents' cyber-intimate image diffusion through social networking sites may grossly be influenced. However, the influence of religious affiliation and spirituality on risky sexual behaviours such as sexual/intimate image diffusion among deaf adolescents is yet unknown.

Spirituality is a complex phenomenon that is inextricably attached to religious affiliation and practices. It is a complex term that significantly shapes lifestyle and biological needs such as seeking sexual attention through social networking sites or through other means. According to Spencer (2012), spirituality is the individualistic drive towards the achievement of a sense of purpose and peace with others. Studies also established the role of spirituality on a variable concept that influences human existence and social interaction (Malinakova et al., 2019; Smith \& Snell, 2009) but the dearth of studies which have considered the level of spirituality of the deaf vis-à-vis risky health, social, and sexual behaviours such as sexting and sexual/intimate image diffusion is surprising. However, Smith and Snell (2009) linked levels of spirituality to the use of and visits to social networking sites. Nicholas and Durrheim (1995) as well as Wallace and Forman (1998) in their cross-sectional studies identified that an increased level of spirituality and devoutness was associated with less frequency of intercourse, increased rates of premarital abstinence, and lower sexting tendency.

Certain attributes of adolescence (non-deaf adolescents) such as sexual experimentation and exploration as well as activities associated with risky sexual behaviours have been linked to variations in personality differences (Crimmins \& Seigfried-Spellar, 2017) and self-esteem 
(Klettke et al., 2019; Ybarra \& Mitchell, 2014). However, findings among the nondeaf population about the implication of self-esteem and sexting are inconclusive. For instance, the study of Abeele et al. (2012), as well as Gordon-Messer et al. (2013), reported that self-esteem had no correlation with sexting behaviour among adolescents whereas Ybarra and Mitchell (2014) stated that sexting and diffusion of sexually suggestive images among adolescents were largely predicted by selfesteem. In other words, variations exist between how adolescents with low selfesteem and their counterpart with higher self-esteem may engage in activities that may lead to the sharing of sexual/intimate images over cyberspace. While previous studies have identified the self-esteem as predictors of sexting and sexual/intimate image diffusion among non-adolescents, there is yet to be an established study which has revealed any implication of self-esteem in the engagement of deaf adolescents in sharing of sexually suggestive image or contents over the social networks.

This study further hypothesised emotional intelligence as a construct plays a crucial role in an individual's success, social engagement, and ultimately mental health (Goleman, 1995), and could predict the tendency to engage in cyber-intimate image diffusion among deaf adolescents. Emotional intelligence is a construct associated with an individual's capacity to identify and manage their emotions, as well as those of others. As indicated by Mayer and Salovey (1997) and Goleman
(1998), more than intelligent quotients, emotional intelligence largely influence all aspects of human interaction, emotional development, and maturity. Unfortunately, Pujar and Patil (2019) stated that deaf adolescents had a high risk for emotional distress, behavioural problems, difficulties with the emotional process, and ultimately lower emotional intelligence due to lack of ability to understand and respond to verbal communication. However, unlike the assertion of Pujar and Patil (2019), Mayer and Salovey (1993) noted that emotional intelligence was a phenomenon that incorporated verbal and non-verbal cues. In other words, emotional intelligence has the capacity to influence non-verbal behaviours, communication, and decision making. Thus, it could be assumed that variation in the level of emotional intelligence may influence intimate image diffusion through the social networking site. In a study, Newness et al. (2012), found that individuals with high emotional intelligence disclosed lesser inappropriate content over Facebook. Similarly, Schuttle et al. (2002) averred that individuals with higher emotional intelligence had a positive mood, positive self-perception and worth, while there was a negatively higher correlation between individuals with a lower level of emotional intelligence and anxiety, depression, and stress.

Digital devices and the autonomy of adolescents' use of the internet and social networking sites have increased in the last two decades. Based on the reported increase (Temple \& Lu, 2018), Penado et 
al. (2019) raised concern about the alarming rate of diffusion of sexual/intimate images over social networking sites among nondeaf adolescents. Unfortunately, many adolescents who engaged in reckless intimate image diffusion have experienced or are currently experiencing attendant negative effects (such as sextortion, victimisation, cyberbullying, loss of privacy, isolation, depression, and ultimately suicide ideation) of reckless diffusion of intimate images over the social networking sites (Bates, 2017; Drouin, 2015). Although research attention has been directed to modalities to arrest the ugly phenomenon among non-deaf adolescents, there is no established study that has directed research attention to intimate image diffusion among deaf adolescents. Therefore, some psychosocial variables that could determine cyber-intimate image diffusion among in-school deaf adolescents from Nigeria were examined in this study.

\section{Theoretical Framework}

This study is hinged on the Theory of Planned Behaviour (TPB) (Ajzen, 1991). The theory is designed to explain and predict intentions and behaviours which could be planned or deliberate. According to Ajzen (1991), an inverse relationship exists between intentions and emotion with a resultant influence on behaviour based on an individual's belief and strength. However, some recent studies, for instance, Wolff et al. (2011), on the direction of the relationship between intention and behaviour, posited that there was a direct link between emotion and behaviour.
Irrespective of the directional effects, TPB captures variables or factors that predict willingness to try out a task, efforts exerted to exhibit or perform a behaviour as well as decisions taken by an individual. Since 1991, TPB has been used to predict and determine human behaviour and reaction to diverse phenomena (Hasbullah et al., 2014; Wolff et al., 2011) but recent studies have engaged TPB to describe the predictor of technology acceptance and use (Hasbullah et al., 2014; Sanne \& Wiese, 2018). Despite these studies, there is yet to be established research especially among deaf adolescents that have engaged the TBP as a model to predict the influence of various psychosocial variables (such as the age of an individual, gender, religious affiliation, dimensions of spirituality, self-esteem, and emotional intelligence) on how adolescents engage in cyber-intimate image diffusion. Therefore, based on established principles of TPB that behaviours are purposive and driven by intentional self-controlled processes, this study assessed psychosocial determinants of cyber-intimate image diffusion among deaf adolescents from North-Central Nigeria.

Specifically, the objectives of this study are to:

1. determine any relationship exists between some psychosocial factors (spirituality, self-esteem, and emotional intelligence) and cyberintimate image diffusion among in-school deaf adolescents.

2. establish the difference between dichotomised psychosocial factors (age, gender, religion, spirituality, 
self-esteem, and emotional intelligence) and cyber-intimate image diffusion among in-school deaf adolescents.

Based on the stated objective, this study, therefore, hypothesised that:

$\mathrm{H} 0_{1}$ : There is no significant relationship between psychosocial factors (age, gender, religion, spirituality, self-esteem, and emotional intelligence) and cyber-intimate image diffusion among in-school deaf adolescents.

$\mathrm{HO}_{2}$ : There is no significant difference between dichotomised psychosocial factors (age, gender, religion, spirituality, selfesteem, and emotional intelligence) and cyber-intimate image diffusion among inschool deaf adolescents.

\section{MATERIALS AND METHODS}

\section{Sampling}

This cross-sectional study was conducted among in-school deaf adolescents in Kwara State and the Federal Capital Territory (FCT) Abuja in North Central, Nigeria between September, 2 and 26, 2019. The study purposively selected two schools for the deaf in the Kwara States and three in the FCT, Abuja based on the population of the students. The selected schools were government-funded secondary schools located within the urban centres. Also, the study purposively selected deaf adolescents from grade 8 and grade 12 aged 13-19 who had access to and actively use social networking sites. A simple random technique was used to select 186 deaf adolescents from the selected schools with a total of
97 (31\% male; 69\% female) respondents from Kwara State and 89 (36\% male; 64\% female) respondents from the FCT, Abuja. All respondents had access to smartphones with internet access and they had used it consistently in the last six months prior to the study. Respondents had profiles on 2 to 3 different social networking sites.

\section{Procedure}

The study recruited the respondents after permission had been sought from the school authorities. The head of schools were adequately briefed about the aim of the study. The head of schools assigned the school counsellor to guide and observe the procedures of data collection. Also, through the Executives of the schools' Parents Teachers Association, permission to conduct the study among deaf adolescents in the schools was sought and received. Written informed consent was secured from all respondents above 16 years of age, while parents/legal guardians gave their consent on behalf of all respondents below the age of 16 . Through sign language which serves as a means of communication among the deaf, all sampled respondents were adequately informed about the need and implication of the study, and they were assured of confidentiality, anonymity, and privacy of their identities and information provided. The research instrument in a paper-pencil printed format was given to the respondents in a conducive environment devoid of external interference. Respondents completed all measures of the scale in an average of 24 minutes. This study ensured 
that all ethical principles guiding the use of human participants in the research were observed.

\section{Measures}

Sociodemographic Characteristics: A total of 186 deaf adolescents participated in this study with about $35 \%$ and $65 \%$ of the respondents being between the ages of 13-15 and 16-19 respectively. The percentage of male respondents was about $33 \%$ while the percentage of female respondents was $67 \%$. A greater response rate of $69 \%$ was obtained from Christian deaf adolescents and 31\% of Muslims volunteered to participate in the study while none of the participants belongs to traditional or other religions. All respondents in this study used WhatsApp as a means of communication and social interaction, $87 \%$ had Facebook profiles, $35 \%$ had an Instagram account, and only about $12 \%, 7 \%$, and $1 \%$ had a social networking profile on $2 \mathrm{go}$, Eskimi, and ToTok respectively. In about 30 days prior to data collection, a total of $108(58.1 \%)$ deaf adolescents reported that they had sent sexual/intimate image over at least one of the social networking sites while $116(62.4 \%)$ of the respondents indicated that they had received intimate images or sexually suggestive contents on social networking sites in the last 30 days before the study.

Intimate Image Diffusion: The respondents answered the 19-item Intimate Image Diffusion Scale developed by Penado et al. (2019). The scale is a two-section scale that measures intimate image diffusion through chat and intimate image diffusion through social networking sites. The scale is designed in a 5-point Likert scale of 1-'Never', 2 - 'Rarely', 3- 'Occasionally', 4 - 'Often' and 5 - 'Frequently'.

Self-esteem: The self-esteem of the respondents was assessed with the Rosenberg Self-esteem Scale (RSES) (Rosenberg, 1965). The self-esteem scale is a 10 -item scale that has 5 positively worded and 5 negatively worded statements. The 5 negatively worded statements were reversed during data coding. Items on the RSES were scored on a 4-point Likert scale of 1- 'strongly disagree', 2- 'disagree', 3- 'agree', and 4- 'strongly agree'. In this study, self-esteem scores between 0-29 represented low self-esteem, while scores of 30 above represented high self-esteem.

Emotional Intelligence: The 33-item Schutte Self Report Emotional Intelligence Test (SSEIT) was used to assess the general emotional intelligence of the respondents. SSEIT developed by Schutte, et al. (1998) is a self-reported instrument designed to map the models of EI as indicated by Salovey and Mayer (1990). All the 33 items of SSEIT measured on a 5-point Likert scale of $1=$ 'strongly disagree' to $5=$ 'strongly agree' were related to utilization; regulation; appraisal and expression of emotion. In this study, scores lower than 93 represented lower emotional intelligence while scores between 93 to 120 denoted a higher emotional intelligence. 
Spirituality: The spirituality scale (SS) developed by Delaney (2003) was used to measure the spirituality of the respondents. The spirituality scale is a 23 -item selfreported scale. Items (e.g Prayer is an integral part of my spiritual nature) were scored in a 6-point response format of $1=$ 'Strongly Disagree' to $6=$ 'Strongly Agree'. Based on the respondent's total score on the spirituality scale, scores of 178 and below represented lower spirituality level while scores of 179 to 201 denoted a higher spirituality level.

\section{Reliability and Validity}

The entire instrument used in this study was pilot-tested among some in-school deaf adolescents from Lagos state, Southwest, Nigeria. The inter-rater reliability of the intimate image diffusion scale was found reliable at Cronbach alpha of .75 while the RSES, SSEIT, SS subscales had a Cronbach alpha of $.86, .77$, and .78 respectively.

\section{Data Analysis}

Data generated were analysed using the descriptive statistics of frequency counts and simple percentages to describe the characteristics of the respondents vis-àvis age, gender, and religious affiliation. The inferential statistics involving Pearson Product Moment Correlation and Independent Samples T-Test at .05 level of significance was used to test the stated hypotheses. Pearson Product Moment Correlation was used to determine the relationship between spirituality, self-esteem, emotional intelligence, and cyber-intimate image diffusion among in-school deaf adolescents while the Independent Samples T-Test was used to determine whether there is a statistically significant difference between dichotomised psychosocial factors (age, gender, religion, spirituality, self-esteem, and emotional intelligence) and cyber-intimate image diffusion among in-school deaf adolescents.

\section{RESULTS}

\section{Hypothesis Testing}

$\mathrm{HO}_{1:}$ There is no significant relationship between psychosocial factors (age, gender, religion, spirituality, self-esteem, and emotional intelligence) and cyber-intimate image diffusion among in-school deaf adolescents.

Table 1 reveales the correlation between some identified psychosocial factors (emotional intelligence, selfesteem and spirituality) and cyberintimate image diffusion among the deaf adolescents. The table also shows a positive significant relationship between emotional intelligence $(r=.489 ; p<0.05)$ as well as self-esteem $(r=.530 ; p<0.05)$ and cyber-intimate image diffusion among observed deaf adolescents from North Central Nigeria. This study showed no significant relationship existed between age of respondents $(r=-.049, \mathrm{p}>0.05)$, gender $(r=.056, p>0.05)$, spirituality $(\mathrm{r}=.065, \mathrm{p}>0.05)$ and cyber-intimate image diffusion among the deaf adolescents from North Central Nigeria. Therefore, the hypothesised statement that there is no significant relationship between emotional 
Table 1

Bivariate correlation between psychosocial factors and cyber-intimate image diffusion

\begin{tabular}{|c|c|c|c|c|c|}
\hline Variable & & 1 & 2 & 3 & 4 \\
\hline \multirow{2}{*}{$\begin{array}{l}\text { Intimate } \\
\text { image } \\
\text { diffusion }\end{array}$} & $\begin{array}{l}\text { Pearson } \\
\text { Correlation }\end{array}$ & 1 & $.489 * *$ & $.530 * *$ & .065 \\
\hline & $\begin{array}{l}\text { Sig. } \\
\text { (2-tailed) }\end{array}$ & & .000 & .000 & .379 \\
\hline \multirow[t]{2}{*}{$\begin{array}{l}\text { Emotional } \\
\text { intelligence }\end{array}$} & $\begin{array}{l}\text { Pearson } \\
\text { Correlation }\end{array}$ & & 1 & $.323 * *$ & .082 \\
\hline & $\begin{array}{l}\text { Sig. } \\
\text { (2-tailed) }\end{array}$ & & & .000 & .263 \\
\hline \multirow[t]{2}{*}{ Self-esteem } & $\begin{array}{l}\text { Pearson } \\
\text { Correlation }\end{array}$ & & & 1 & .028 \\
\hline & $\begin{array}{l}\text { Sig. } \\
\text { (2-tailed) }\end{array}$ & & & & .706 \\
\hline Spirituality & $\begin{array}{l}\text { Pearson } \\
\text { Correlation }\end{array}$ & & & & 1 \\
\hline \multicolumn{2}{|l|}{ Mean } & 58.387 & 94.290 & 26.037 & 169.483 \\
\hline \multicolumn{2}{|c|}{ Standard Deviation } & 12.603 & 14.820 & 4.389 & 19.206 \\
\hline
\end{tabular}

Note: $* *$ Correlation is significant at the .01 level (2-tailed)

intelligence, self-esteem and cyber-intimate image diffusion among in-school deaf adolescents is not accepted.

$\mathrm{HO}_{2}$ : There is no significant difference between dichotomised psychosocial factors (age, gender, religion, spirituality, selfesteem, and emotional intelligence) and cyber-intimate image diffusion among inschool deaf adolescents.

Table 2 sought to determine the significant difference in the dichotomised psychosocial variables and cyber-intimate image diffusion among the respondents of this study. As captured in Table 3, there was a significant difference between deaf adolescents who were affiliated with Christianity $(\bar{X}=63.720)$ and Islam $(\bar{X}=46.315)$ with respect to cyber-intimate image diffusion. The result showed that there was a likelihood of deaf adolescents who were Christians to engage in cyber-intimate image diffusion than their counterparts who were practicing Islam. Also, a significant difference between deaf adolescents with lower emotional intelligence $(\bar{X}=56.163)$ and higher emotional intelligence $(\bar{X}=60.563)$ with respect to cyber-intimate intimate image diffusion was observed. These results indicate that deaf adolescents with higher emotional intelligence have lower potentials to engage in cyber-intimate image diffusion. 
Furthermore, the table showed a significant deaf adolescents with lower self-esteem difference in cyber-intimate image diffusion have a higher tendency to engage in cyber between deaf adolescents with low self- activities that diffuse sexual/intimate images esteem $(\bar{X}=47.046)$ and higher self- when compared with others with high selfesteem $(\bar{X}=64.479)$. This implies that esteem.

Table 2

T-test showing differences between the independent variables and the dependent variable

\begin{tabular}{|c|c|c|c|c|c|c|c|}
\hline & & $\mathrm{N}$ & Mean & Std Dev & Df & $\mathrm{t}$-cal & Sig \\
\hline \multirow[t]{2}{*}{ Age } & $13-15$ years & 66 & 59.212 & 13.689 & 184 & .661 & .509 \\
\hline & $16-19$ years & 120 & 57.933 & 11.999 & & & \\
\hline \multirow[t]{2}{*}{ Religion } & Christianity & 129 & 63.720 & 9.185 & 184 & 11.250 & .000 \\
\hline & Islam & 57 & 46.315 & 10.864 & & & \\
\hline \multirow[t]{2}{*}{ Gender } & Male & 62 & 57.387 & 8.122 & 184 & -.764 & .446 \\
\hline & Female & 124 & 58.887 & 14.332 & & & \\
\hline \multirow[t]{2}{*}{$\begin{array}{l}\text { Emotional } \\
\text { intelligence }\end{array}$} & $\begin{array}{l}\text { Low } \\
\text { emotional } \\
\text { intelligence }\end{array}$ & 92 & 56.163 & 14.054 & 184 & -2.412 & .017 \\
\hline & $\begin{array}{l}\text { High } \\
\text { emotional } \\
\text { intelligence }\end{array}$ & 94 & 60.563 & 10.631 & & & \\
\hline \multirow[t]{2}{*}{ Self-esteem } & $\begin{array}{l}\text { Low self- } \\
\text { esteem }\end{array}$ & 65 & 47.046 & 8.090 & 184 & -11.958 & .000 \\
\hline & $\begin{array}{l}\text { High self- } \\
\text { esteem }\end{array}$ & 121 & 64.479 & 10.143 & & & \\
\hline \multirow[t]{2}{*}{ Spirituality } & $\begin{array}{l}\text { Lower level } \\
\text { of spirituality }\end{array}$ & 115 & 56.422 & 12.784 & 184 & -1.679 & .095 \\
\hline & $\begin{array}{l}\text { Higher level } \\
\text { of spirituality }\end{array}$ & 71 & 59.600 & 12.390 & & & \\
\hline
\end{tabular}

\section{DISCUSSIONS}

This study assessed the psychosocial determinants of cyber-intimate image diffusion among deaf adolescents from North Central Nigeria in other to fill the existing research gap on the construct of sexting or cyber-intimate image diffusion. Therefore, justification and discussion were completed with many references to studies from the non-deaf adolescents' population. 
In line with the study objectives, the study hypothesised that there is no significant relationship between identified psychosocial factors (emotional intelligence, self-esteem, and spirituality) and cyber-intimate image diffusion among deaf adolescents.

Findings in this study revealed that emotional intelligence and self-esteem significantly correlated with cyber-intimate image diffusion among deaf adolescents. While this current study was conducted among deaf adolescents, the findings obtained on the relationship between religiosity and cyber-intimate image diffusion are similar to previously reported findings, although among non-deaf adolescents. Some studies have linked emotional intelligence to adolescents' behaviour, social interaction, and engagements (Liu, 2010; Tissaa, 2019). Studies of Liu (2010) and Tissaa (2019) stated that individuals with regular participation in religious rituals had stronger emotional stability and lesser tendencies to engage in risky behaviours which may include cyber-intimate image diffusion. According to Goleman (1998) and Tissaa (2019), emotional intelligence has a substantial influence on emotional development, stability, and human interaction especially over cyberspace and various social networking sites. From the findings in this study, there was a positive relationship between emotional intelligence and cyber-intimate image diffusion among deaf adolescents. This corroborates Silva et al. (2016) and Ugoji (2014) who had reported a positive significant relationship between emotional intelligence and reported sexual practice, functioning, and diffusion of intimate contents among adolescents. On the contrary, this finding does not correspond with some other previous studies (Ortiz, 2012; Wozniak, 2013) which reported an insignificant relationship between adolescents' sexual expression and emotional intelligence.

Also, this study found a significant positive relationship between self-esteem and cyber-intimate image diffusion among deaf adolescents. This implies that deaf adolescents with a sense of self-worth, high moral value with a positive perception of themselves would not engage in activities associated with the diffusion of sexual/ intimate images through social networking sites. This finding, though among deaf adolescents, supports earlier studies such as Ellison et al (2007), Scholes-Balog et al. (2016), as well as Vogel et al. (2014) while it negates the findings of Abeele et al. (2012), Crimmins and Seigfried-Spellar (2017), as well as Gordon-Messer et al. (2013) who reported no significant relationship between self-esteem and sexting (sending and receiving intimate images) among adolescents. According to Ellison et al (2007), self-esteem is a major factor that influences online presence and usage of social networking sites by adolescents. As stated by Ellison et al (2007), selfesteem is attributed to psychosocial adjustment, models of social interaction, and communication through social networking sites among adolescents.

Furthermore, the findings of this study with regard to the second hypothesis showed 
significant differences in cyber-intimate image diffusion among deaf adolescents based on the dichotomized variables of religion (Christian and Muslim), emotional intelligence (high and low), and self-esteem (high and low) as shown on Table 2. Results in Table 2 show that deaf adolescents with affiliation to Christianity had a higher mean score than their counterparts with Islamic affiliation. This implies that deaf adolescents who were Christians may engage in cyber-intimate image diffusion than their counterparts who were Muslims. Irrespective of religion, sexting, and diffusion of sexually explicit images and content on virtual space through elements of social networking sites remains a challenging and incomprehensible discourse based on morality, security, and religious dimensions. The issues of cyber-intimate image diffusion or sext as it may seem to be discussed more among Christians based on the population of participants recorded in various studies (Cindoglu, 2003; Hasinoff, 2014) even as shown in this study where about $69 \%$ of the respondents were Christians. Hence while few studies have explored the differences in sexual exploration over the cyber media, this study supports Hasinoff (2014) who had previously observed a low frequency of sexting behaviour among Muslim adolescents. This finding may be associated with philosophies of namus (honour), prevailing religious practices, and stringent punishment attached to pre-marital sexual activities in Islam as indicated by Cindoglu (2003).
The capacity to regulate one's emotion is an integral part of emotional intelligence which serves as a buffer for risky sexual behaviour (Sesar et al., 2019) such as engaging in cyber-intimate image diffusion. In other words, levels of emotional intelligence among deaf adolescents as hypothesized in this study influence their potential to engage in cyber-intimate image diffusion. In this study, deaf adolescents with a high level of emotional intelligence as shown in Table 3 were found to have a higher mean score than their counterparts with low emotional intelligence. Hence, they possess a lower probability to engage in cyber-intimate image diffusion. This finding is consistent with Currò's, (2017) who noted that adolescents stood to engage in sexting and other risky sexual behaviours when they exhibited challenges with the ability to understand and regulate emotion particularly when under peer pressure. Since cyber-intimate image diffusion is an activity between two individuals, the pressure to sex chat via social networking sites may be more from one person to the other. Hence, deaf adolescents with a higher level of emotional intelligence may therefore resist the request. As stated by Brackett et al. (2004), Goleman (1995), and Mayer et al. (2000), individuals with a higher level of emotional intelligence are expected to have an adaptive defence mechanism that acts as a buffer against peer pressure, deviant behaviour, and engagement in sexual activities such as sexting and sharing or intimate or sexually explicit images. 
The finding of this study based on dimensions of high and low self-esteem and cyber-intimate image diffusion is not in tandem with two previous studies that had investigated sexting (sending and receiving intimate images) and levels of self-esteem which reported no significant difference across levels of self-esteem and activities associated with sending and receiving sexual/intimate images among adolescents (Abeele et al., 2012; GordonMesser et al., 2013). Unlike the report of Gordon-Messer et al. (2013), this current study supports Scholes-Balog et al. (2016) who found differences between levels of self-esteem and how adolescents sent nude photos or videos. In line with the studies of Preston et al. (2004) and the theory of planned behaviour (Ajzen, 1991), this study identified lower self-esteem as a construct that is associated with increased potential to engage in sexual activities associated with sending and receiving sexual intimate images or content while deaf adolescents with high self-esteem have lesser tendency to engage in such activity based on their perception of self-worth and morality.

\section{CONCLUSIONS}

This study revealed a significant relationship between religion, emotional intelligence, self-esteem, and cyber-intimate image diffusion among deaf adolescents from North Central Nigeria. However, neither significant relationship nor differences were found between age (early and late adolescence), gender (male and female), spirituality (low and high), and cyber-intimate image diffusion among the respondents in this study. This implies that cyber-intimate image diffusion is a phenomenon largely predicted by more psychological than social determinant factors. Therefore, the role of psychological determinants of cyberintimate image diffusion makes it imperative for an urgent concerted effort by parents, teachers, school counselling psychologists to promote activities that will foster positive psychological development among deaf adolescents. Through various means of communication such as sign language, social networking sites, lip-reading, or other means of communication within the home, parents need to engage their deaf children in a discussion about sexuality, their online friends, interactions, and activities. Also, teachers should be watchful of red-flags associated with cyber trauma arising from cyberbullying, sextortion, and harassment among deaf learners. Teachers are enjoined to adequately report and make referrals to the appropriate professionals for counselling. Furthermore, school counselling psychologists should in collaboration with teachers and parents of deaf learners engage in effective behavioural and emotional interventions geared towards the deconstruction of cyber-intimate image diffusion among deaf adolescents, and the development of positive communication and interaction on social networking sites.

Although findings from this present study provide new information about cyber-intimate image diffusion among deaf adolescents as determined by some psychosocial factors, there exist some 
limitations that this study needs to acknowledge. The population of respondents in this study was a representative sample of deaf adolescents from North Central Nigeria with a non-equal gender proportion of respondents. The non-equal representation of the gender of respondents who participated in this study was largely due to the high population of in-school female deaf adolescents within the age bracket (13-19) considered in this study. Also, determinants of cyber-intimate image diffusion examined in this study are not exhaustive as there are other variables such as parental/family status, birth order, peer pressure, home/school environmental factors of the respondents that may influence the engagement of deaf adolescents in cyber-intimate diffusion. Also, this study used quantitative approaches that limit the responses of the respondents. Therefore, future research efforts on cyber-intimate image diffusion may consider a larger sample of deaf adolescents from different races, ethnicity, or nations. Qualitative studies and longitudinal approach to data collection of determinants of cyber-intimate image diffusion among deaf adolescents are encouraged.

Despite these limitations, results from the present study have provided some insights regarding the influence of religion, emotional intelligence, and self-esteem on cyber-intimate image diffusion among deaf adolescents. In particular, these findings may provide counselling psychologists, parents, and teachers of deaf learners with sufficient understanding of the role each of the constructs measured in this study could play on cyber-intimate image diffusion among deaf adolescents. Lastly, in an attempt to mitigate negative consequences associated with reckless cyber-intimate image diffusions such as cyber-harassment, cyber-bulling, or sextortion (Kaur, 2014) which may lead to suicidal thoughts and or attempts, this study should serve as a springboard for developing therapeutic approaches aimed at enhancement of psychosocial wellbeing of deaf adolescents.

\section{ACKNOWLEDGEMENTS}

The author appreciates all deaf adolescents who participated in this study and also appreciate all officers and administrators who granted permission for the conduct of this study. The author acknowledges Ms. Faisat Tijani for assistance rendered during data collection.

\section{REFERENCES}

Abeele, M. V., Roe, K., \& Eggermont, S. (2012). An exploration of adolescents' sexual contact and conduct risks through mobile phone use. Communications, 37(1), 55-77. https://doi. org/10.1515/commun-2012-0003

Adigun, O. T. (2018). Basic education in Nigeria: Any concern for Special needs education? The Journal of Advocacy and Rehabilitation, 17(1), 27-37.

Adigun, O. T. (2020). Self-esteem, self-efficacy, selfconcept and intimate image diffusion among Deaf adolescents: A structural equation model analysis. Heliyon, 6(8), e04742. https://doi. org/10.1016/j.heliyon.2020.e04742

Ajzen, I. (1991). The theory of planned behavior. Organizational Behavior and Human 
Decision Processes, 50(2), 179-211. https://doi. org/10.1016/0749-5978(91)90020-T

Anderson, M., \& Jiang, J. (2018). Teens, social media \& technology. Pew Research Center. Retrieved November 14, 2019, from http://www. pewinternet.org/2018/05/31/teens-social-mediatechnology-2018/.

Apostolides, A. (2017). Cyber bullying: Child and youth spirituality. HTS Theological Studies, 73(3), a4692. http://dx.doi.org/10.4102/ hts.v73i3.4692

Bankole, A., \& Malarcher, S. (2010). Removing barriers to adolescents' access to contraceptive information and services. Studies in Family Planning, 41, 117-124. https://doi.org/10.1111/ j.1728-4465.2010.00232.x

Barak, A., \& Sadovsky, Y. (2008). Internet use and personal empowerment of hearing impaired adolescents. Computer in Human Behaviour, 24, 1802-1815. https://doi.org/10.1016/j. chb.2008.02.007

Bates, S. (2017). Revenge porn and mental health: A qualitative analysis of the mental health effects of revenge porn on female survivors. Feminist Criminology, 12, 22-42. https://doi. org/10.1177/1557085116654565

Bontempo, K. (2015). Signed language interpreting. The Routledge handbook of interpreting. Oxon, England: Routledge.

Brackett, M. A., Mayer, J. D., \& Warner, R. M. (2004). Emotional intelligence and its relation to everyday behavior. Personality and Individual Differences, 36, 1387-1402. https://doi. org/10.1016/S0191-8869(03)00236-8

Cindoglu, D. (2003). Modern türk tıbbında bekaret testleri ve suni bekaret [Virginity tests and artificial virginity in modern Turkish medicine]. In P. Ilkkaracan (Ed.), Müslüman toplumlarda kadın ve cinsellik [Women and sexuality in
Muslim societies]. Istanbul, Turkey: İletişim Yayınları.

Crimmins, D. M., \& Seigfried-Spellar, K. C. (2017). Adults who Sext: Exploring differences in self-esteem, moral foundations, and personality. International Journal of Cyber Criminology, 11(2), 169-182. doi:10.5281/ zenodo.1037379

Currò, F. (2017). The influence of technology in interpersonal relationships: The case of sexting (Diploma thesis, University of Milan, Italy). Retrieved from June 13, 2020, from https:// www.researchgate.net/publication/316685010 L'influenza_della_tecnologia_nelle_relazioni interpersonali_il_caso_del_sexting_The influence_of_technology_on_interpersonal_ relationships_the_case_of_sexting.

Delaney, C. (2003). The spirituality scale: Development, refinement and psychometric testing of an instrument to assess the human spiritual dimension (Doctoral dissertation, University of Connecticut, USA). Retrieved March 30, 2020, from https://opencommons. uconn.edu/dissertations/AAI3118943

De Visser, R. O., Smith, A. M., Richters, J., \& Rissel, C. E. (2007). Associations between religiosity and sexuality in a representative sample of Australian adults. Archives of Sexual Behavior, 36(1), 33-46. https://doi.org/10.1007/ s10508-006-9056-0

Drouin, M., Ross, J., \& Tobin, E. (2015). Sexting: A new, digital vehicle for intimate partner aggression? Computer in Human Behaviour, 50, 197-204. https://doi.org/10.1016/j. chb.2015.04.001

Ellison, N. B., Steinfield, C., \& Lampe, C. (2007). The benefits of Facebook "friends": Social capital and college students' use of online social network sites. Journal of Computer-Mediated Communication, 12(4), 1143-1168. https://doi. org/10.1111/j.1083-6101.2007.00367.x 
Englander, E., \& McCoy, M. (2018). Sexting Prevalence, age, sex, and outcomes. JAMA Paediatrics, 172(4), 317-318. https://doi. org/10.1001/jamapediatrics.2017.5682

Goleman, D. (1995). Emotional intelligence: Why it can matter more than IQ. London, England: Bantam Books.

Goleman, D. (1998). Working with emotional intelligence. New York, USA: Bantam Books.

Gordon-Messer, D., Bauermeister, J. A., Grodzinski, A., \& Zimmermanm, M. (2013). Sexting among young adults. Journal of Adolescent Health, 52, 301-306. https://doi.org/10.1016/j. jadohealth.2012.05.013

Harrison, M. A., \& Gilmore, A. L. (2012). U txt WHEN? College students' social contexts of text messaging. The Social Science Journal, 49(4), 513-518. https://doi.org/10.1016/j. soscij.2012.05.003

Hasbullah, N., Mahajar, A. J., \& Salleh, M. I. (2014). A conceptual framework of extending the theory of planned behavior: The role of service quality and trust in the consumer cooperatives. International Journal of Business and Social Science, 5(12), 142-148. Retrieved July 11, 2020, from https://ijbssnet.com/journals/ vol_5_no_12_november_2014/17.pdf

Hasinoff, A. A. (2014). Blaming sexualization for sexting. Girlhood Studies, 7(1), 102-120. https:// doi.org/10.3167/ghs.2014.070108

Kaur, P. (2014). Sexting or pedophilia? Revista Criminalidad, 56(2), 263-272. Retrieved June 12, 2020, from http://www.scielo. org.co/scielo.php?script=sci_arttext\&pid $=$ S1794-31082014000200006.

Klettke, B., Hallford, D. J., \& Mellor, D. J. (2014). Sexting prevalence and correlates: A systematic literature review. Clinical Psychology Review, 34(1), 44-53. https://doi.org/10.1016/j. cpr.2013.10.007
Klettke, B., Hallford, D. J., Clancy, E., Mellor, D. J., \& Toumbourou, J. W. (2019). Sexting and psychological distress: The role of unwanted and coerced sexts. Cyberpsychology, Behavior, and Social Networking, 22(4), 237-242. doi:10.1089/ cyber.2018.0291

Kopecký, K. (2012). Sexting among Czech preadolescents and adolescents. The New Educational Review, 28(2), 39-48. Retrieved November 11, 2020, from https://www. researchgate.net/publication/236019455 Sexting_among_Czech_Preadolescents_and_ Adolescents.

Lawrence, K. C., \& Tokede, A. M. (2017). Pubertal maturation, sexting and social network utilization in relation to online dating behaviour among adolescents in the University of Ibadan. Ibadan Journal of Educational Studies, 12(2), 26-32.

Lenhart, A., Purcell, K., Smith, A., \& Zickuhr, K. (2010). Social media \& mobile internet use among teens and young adults. Retrieved September 20, 2011, from http://samaritanbehavioralhealth.net/ files/social-media-young-adults.pdf

Lindsay, M., \& Krysik, J. (2012). Online harassment among college students. Information, Communication \& Society, 15(5), 706-707. https://doi.org/10.1080/1369118X.2012.674959

Lippman, J. R., \& Campbell, S. W. (2014). Damned if you do, damned if you don't... if you're a girl: Relational and normative contexts of adolescent sexting in the United States. Journal of Children and Media, 8(4), 371-386. https://doi.org/10.10 80/17482798.2014.923009

Liu, C. C. (2010). The relationship between personal religious orientation and emotional intelligence. Social Behavior and Personality: An International Journal, 38, 461-468. https:// doi.org/10.2224/sbp.2010.38.4.461

Livingstone, S., \& Görzig, A. (2014). When adolescents receive sexual messages on the internet: Explaining experiences of risk and 
harm. Computers in Human Behavior, 33, 8-15. https://doi.org/10.1016/j.chb.2013.12.021

Madigan, S., Ly, A., Rash, C. L., Van Ouytsel, J., \& Temple, J. R. (2018). Prevalence of multiple forms of sexting behavior among youth: A systematic review and meta-analysis. JAMA Pediatrics, 172(4), 327-335. https://doi. org10.1001/jamapediatrics.2017.5314

Malinakova, K., Kopcakova, J., Geckova, A. M., van Dijk, J. P., Furstova, J., Kalman, M., \& Reijneveld, S. A. (2019). "I am spiritual, but not religious": Does one without the other protect against adolescent health-risk behaviour? International Journal of Public Health, 64(1), 115-124. https://doi.org/10.1007/s00038-0181116-4

Marume, A., Maradzika, J., \& January, J. (2018). Adolescent sexting and risky sexual behaviours in Zimbabwe: A cross-sectional study. Sexuality \& Culture, 22(3), 931-941. https://doi.org/10.1007/ s12119-018-9508-4

Mayer, J. D., \& Salovey, P. (1993). The intelligence of emotional intelligence. Intelligence, 17, 433-442. https://doi.org/10.1016/0160-2896(93)90010-3

Mayer, J. D., \& Salovey, P. (1997). What is emotional intelligence? In P. Salovey \& D. J. Sluyter (Eds.), Emotional development and emotional intelligence: Educational implications (pp. 3-34). New York, USA: Harper Collins.

Mayer, J. D., Salovey, P., \& Caruso, D. (2000). Competing models of emotional intelligence. In R. J. Sternberg (Ed.), Handbook of human intelligence (2nd ed., pp. 396-420). New York, USA: Cambridge University Press.

Morelli, M., Bianchi, D., Baiocco, R., Pezzuti, L., \& Chirumbolo, A. (2016). Sexting, psychological distress and dating violence among adolescents and young adults. Psicothema, 28(2), 137-142. https://doi.org/10.7334/psicothema2015.193
Moroe, N. F., \& De Andrade, V. (2018). Hearing children of deaf parents: Gender and birth order in the delegation of the interpreter role in culturally Deaf families. African Journal of Disability, 7, 1-10. https://doi.org/10.4102/ajod. v7i0.365.

Napier, J., \& Barker, R. (2004). Sign language interpreting: The relationship between metalinguistic awareness and the production of interpreting omissions. Sign Language Studies, 4(4), 369-393. https://doi.org/10.1353/ sls. 2004.0020

Newness, K., Steinert, J., \& Viswesvaran, C. (2012). Effects of personality on social network disclosure: Do emotionally intelligent individuals post inappropriate content? Psihologijske Teme, 21(3), 473-486. Retrieved June 11, 2020 , from https://psycnet.apa.org/ record/2013-03108-005

Nicholas, L., \& Durrheim, K (1995). Religiousity, AIDS and sexuality knowledge, attitude, beliefs and practices of Black South African first year university students. Psychological Report, 77, 1328-1330. https://doi.org/10.2466/ pr0.1995.77.3f.1328

Oluwole, D. A. (2009). Spirituality, gender and age factors in cybergossip among Nigerian adolescents. Cyberpsychology \& Behavior, 12(3), 323-326. https://doi.org/10.1089/cpb.2008.0285.

Ortiz, D. E. (2012). The association between emotional intelligence and sexual risk behavior among undergraduate college students in the Greater Los Angeles (Master thesis, Claremont Colleges, USA). Retrieved March 14, 2020, from https://scholarship.claremont.edu/scripps_ theses/89

Penado, A. M., Marcos, C. M., Rodicio-García, M. L., \& Corrás, V. T. (2019). Construction and validation of the Intimate Images Diffusion Scale among adolescents. Frontiers in Psychology, 10, 1485. https://doi.org/10.3389/fpsyg.2019.01485 
Preston, D. B., D’Augelli, A. R., Kassab, C. D., Cain, R. E., Schulze, F. W., \& Starks, M. T. (2004). The influence of stigma on the sexual risk behavior of rural men who have sex with men. AIDS Education and Prevention, 16(4), 291-303. https://doi.org/10.1521/aeap.16.4.291.40401.

Pujar, L., \& Patil, S. (2019). Emotional intelligence among hearing impaired children. International Journal of Current Microbiology and Applied Sciences, 8(9), 1818-1824. https://doi. org/10.20546/ijcmas.2019.809.210

Quinn, D. A., \& Lewin, A. (2019). Family religiosity, parental monitoring, and emerging adults' sexual behavior. Religions, 10(2), 114-130. https://doi. org/10.3390/rel10020114.

Rai, G. (2017). Impact of social networking sites (SNSs): Are youth affected by its usage? Issues and Ideas in Education, 5(1), 11-24. https://doi. org/10.15415/iie.2017.51001.

Rosenberg, M. (1965). Society and the adolescent selfimage. Princeton, USA: Princeton University Press.

Rostosky, S. S., Wilcox, B. L., Wright, M. L. C., \& Randall, B. A. (2004). The impact of religiosity on adolescent sexual behavior: A review of the evidence. Journal of Adolescent Research, 19(6), 677-697. https://doi. org/10.1177/0743558403260019

Salovey, P., \& Mayer, J. D. (1990). Emotional intelligence. Imagination, Cognition and Personality, 9(3), 185-211. https://doi. org/10.2190/DUGG-P24E-52WK-6CDG

Sangowawa, A. O., Owoaje, E. T., Faseru, B., Ebong, I. P., \& Adekunle, B. J. (2009). Sexual practices of deaf and hearing secondary school students in Ibadan, Nigeria. Annals of Ibadan Postgraduate Medicine, 7(1), 26-30. https://doi.org/10.4314/ aipm.v7i1.64060.

Sanne, P. N., \& Wiese, M. (2018). The theory of planned behaviour and user engagement applied to Facebook advertising. South African Journal of Information Management, 20(1), 1-10. http:// dx.doi.org/10.4102/sajim.v20i1.915.

Scholes-Balog, K., Francke, N., \& Hemphill, S. (2016). Relationships between sexting, self-esteem, and sensation seeking among Australian young adults. Sexualization, Media, \& Society, 2(2), 1-8. https://doi.org/10.1177/2374623815627790.

Schutte, N. S., Malouff, J. M., Hall, L. E., Haggerty, D. J., Cooper, J. T., Golden, C. J., \& Dornheim, L. (1998). Development and validation of a measure of emotional intelligence. Personality and Individual Differences, 25(2), 167-177. https://doi.org/10.1016/S0191-8869(98)00001-4

Schuttle, N. S., Malouff, J. M., Simunek, M., McKenley, J., \& Hollander, S. (2002). Characteristic emotional intelligence and emotional wellbeing. Cognition and Emotion, 16, 769-785. https://doi.org/10.1080/02699930143000482

Sesar, K., Dodaj, A., \& Kordić, A. (2019). Emotional competence and sexting among university students. International Journal of Cyber Criminology, 13(1), 21-37. https://doi. org/10.5281/zenodo.3383446.

Silva, P., Pereira, H., Esgalhado, G., Monteiro, S., Afonso, R. M., \& Loureiro, M. (2016). Emotional intelligence, sexual functioning, and subjective sexual well-being in Portuguese adults. Journal of Education, Society and Behavioural Science, 15(1), 1-11. https://doi. org/10.9734/BJESBS/2016/23481

Smith, C., \& Snell, P. (2009). Souls in transition: The religious and spiritual lives of emerging adults. New York, USA: Oxford University Press.

Spencer, M. (2012). What is spirituality? A personal exploration. Retrieved March 16, 2020, from https://www.rcpsych.ac.uk/docs/ default-source/members/sigs/spiritualityspsig/what-is-spirituality-maya-spencer-x. pdf?sfvrsn=f28df052_2. 
Temple, J. R., \& Lu, Y. (2018). Sexting from a health perspective: Sexting, health, and risky sexual behaviour. In M. Walrave, J. van Ouytsel, K. Ponnet, \& J. R. Temple (Eds.), Sexting (pp. 5361). Chicago, USA: Palgrave Macmillan. https:// doi.org/10.1007/978-3-319-71882-8_4

Tissaa, T. C. (2019). Faith and emotional intelligence. International Journal of Recent Technology and Engineering, 7(5S), 5-7. Retrieved June 11, 2020, from https://www.ijrte.org/wp-content/ uploads/papers/v7i5s/Es211301751919.pdf

Ugoji, F. N. (2014). Determinants of risky sexual behaviours among secondary school students in Delta State Nigeria. International Journal of Adolescence and Youth, 19(3), 408-418. https:// doi.org/10.1080/02673843.2012.751040.

Vogel, E. A., Rose, J. P., Roberts, L. R., \& Eckles, K. (2014). Social comparison, social media, and self-esteem. Psychology of Popular Media Culture, 3(4), 206-222. https://doi.org/10.1037/ ppm0000047

Wallace, J. M., \& Forman, T. A. (1998). Religion's role in promoting health and reducing risk among American youth. Health Education and Behavior, 25, 721-741. https://doi. org/10.1177/109019819802500604
Willard, N. (2010). Sexting and youth: Achieving a rational response. Journal of Social Sciences, 6(4), 542-562. https://doi.org/10.3844/ jssp.2010.542.562

Wolff, K., Nordin, K., Brun, W., Berglund, G., \& Kvale, G. (2011). Affective and cognitive attitudes, uncertainty avoidance and intention to obtain genetic testing: An extension of the theory of planned behaviour. Psychology and Health, 26, 1143-1155. https://doi. org/10.1080/08870441003763253

Wozniak, R. L. (2013). Risky sexual behaviors in adolescence: Their relationship to socialemotional intelligence (Doctoral dissertation, Alfred University, Alfred, USA). Retrieved March 14, 2020, from https://aura.alfred.edu/ bitstream/handle/10829/4862/Wozniak\%2C\%20 Rose $\% 202013$.pdf? sequence $=1 \&$ is Allowed $=y$

Ybarra, M. L., \& Mitchell, K. J. (2014). "Sexting" and its relation to sexual activity and sexual risk behavior in a national survey of adolescents. Journal of Adolescent Health, 55, 757-764. https://doi.org/10.1016/j.jadohealth.2014.07.012 
